\title{
Influence of potassium and sulphur levels on concentration and uptake of nutrients by groundnut at harvest stage
}

S. M. Kharwade, N. R. Mairan and S. D. More

Received : 16.10.2019; Revised : 02.11.2019; Accepted : 12.11 .2019

\section{MEMBERS OF RESEARCH FORUM:}

Corresponding author : S. M. Kharwade, Department of Soil Science and Agricultural Chemistry, Vasantrao Naik Marathwada Krishi Vidyapeeth, Parbhani (M.S.) India

Email: nishapati17806@gmail.com

\section{Co-authors :}

N. R. Mairan and S. D. More, Department of Soil Science and Agricultural Chemistry, Vasantrao Naik Marathwada Krishi Vidyapeeth, Parbhani (M.S.) India

\section{Summary}

A field experiment was conducted in the plot no. A-8 at college farm Department of Agronomy, VNMAU, Parbhani during Rabi season of year 2001-2002. The experiment was laid in a split plot design with 16 treatment combination. Four levels of each potassium and sulphur were taken each treatment was replicated three times. From these experiment the results concluded that the concentration of $\mathrm{N}, \mathrm{P}$ and $\mathrm{S}$ was increased at $60 \mathrm{~kg} \mathrm{~S} \mathrm{ha}^{-1}$ in plant. The $\mathrm{K}$ concentration was recorded at $75 \mathrm{~kg} \mathrm{~K}_{2} \mathrm{O} \mathrm{ha}^{-1}$ level. The uptake of $\mathrm{N}, \mathrm{P}, \mathrm{K}$ and $\mathrm{S}$ increased with the increasing levels of $\mathrm{K}$ and $\mathrm{S}$.

Key words : Potassium, Sulphur, Concentration, Uptake in groundnut

How to cite this article : Kharwade, S.M., Mairan, N.R. and More, S.D. (2019). Influence of potassium and sulphur levels on concentration and uptake of nutrients by groundnut at harvest stage. Asian J. Soil Sci., 14 (1\&2) : 13-19 : DOI : 10.15740/HAS/AJSS/14.1and2/13-19. 